\title{
PENGGUNAAN CREATIVE WRITING HANDBOOK \\ DALAM UPAYA MENGEMBANGKAN KREATIFITAS MAHASISWA PRODI PENDIDIKAN BAHASA INGGRIS UNIVERSITAS KANJURUHAN PADA KELAS INSTRUCTIONAL MEDIA
}

\author{
Irene Trisisca Rusdiyanti, Uun Muhaji \\ Universitas Kanjuruhan Malang
}

\begin{abstract}
Abstrak: Penelitian ini bertujuan untuk mengetahui bagaimana penggunaan Creative Writing Handbook bisa mengembangkan kreatifitas mahasiswa prodi pendidikan Bahasa Inggris Universitas Kanjuruhan Malang sebagai calon guru Bahasa Inggris dalam mata kuliah Instructional Media. Penelitian ini menggunakan Penelitian Tindakan Kelas (PTK) dengan berpusat pada mahasiswa Prodi Pendidikan Bahasa Inggris yang menempuh mata kuliah Instructional Media. Kriteria keberhasilan bagi penelitian ini adalah 80\% dari total jumlah mahasiswa yang mengikuti Mata Kuliah Instructional Media mampu menentukan dan membuat Creative Writing Handbook berdasarkan tujuan pembelajaran yang harus dicapai, dengan nilai minimal 75. Ada 2 siklus dari penelitian ini. Pada siklus yang pertama, mahasiswa yang mencapai nilai akhir 7.5 adalah $68.75 \%$ sedangkan 31,25\% mahasiswa masih mencapai nilai akhir kurang dari 75. Pada siklus kedua, dari 32 mahasiswa yang berhasil mencapai criteria keberhasilan adalah sebesar 93,75\% dan yang gagal mencapai kriteria keberhasilan $6,25 \%$. Secara umum dapat ditarik kesimpulan bahwa penerapan Creative Writing Handbook dapat memecahkan permasalahan yang terjadi. Lebih khusus dapat pula ditarik kesimpulan bahwa dengan penerapan metode ini dapat meningkatkan interaksi antar mahasiswa, interaksi dosen dan mahasiswa, serta dapat pula memecahkan permasalahan yang terjadi di kelas, khususnya untuk mata kuliah instructional media.
\end{abstract}

Kata Kunci: creative writing handbook, penelitian tindakan kelas, variasi pembelajaran

\begin{abstract}
This research aimed to investigate how the use of Creative Writing Handbook could improve the ideas and the creativity of students of English Department, Kanjuruhan University of Malang as the English pre-service teachers in Instructional Media lecture. This research used Classroom Action Research to the English Department students who took Instructional Media. The criteria of success in this research was $80 \%$ of the students who joined Instructional Media could decide and made Creative Writing Handbook based on the learning goal which had to be reached, with minimum score 75 . There were two cycles in this research. In the first cycle, the students who achieved 75 were $68.75 \%$, while $31,25 \%$ students still achieved score less than 75 . In the second cycle, from 32 students, 93,75\% students achieved the criteria of success, and those who failed were $6,25 \%$. It can be concluded that the implementation of creative writing handbook can solve the problem. More specifically, it can be concluded that this method can improve the interaction among the students, and among the students and the lecturer. it can also be used to solve the problem happens in the instructional class.
\end{abstract}

Key words: creative writing handbook, classroom action research, learning variation

\section{PENDAHULUAN}

Perkembangan dunia pendidikan saat ini semakin menantang dengan begitu banyaknya tuntutan yang menyertai media serta peralatan yang semakin canggih yang tersedia di masyarakat. Tantangan yang sejalan dengan perkembangan jaman yang semakin berat ini harus diketahui oleh para calon pendidik yang saat ini sedang menempuh pendidikan sebagai mahasiswa Fakultas Keguruan dan Ilmu Pendidikan. Mereka harus mempersiapkan diri sehingga nantinya sungguh siap dan mampu menghadapi tantangan dalam menerapkan ilmu yang sudah mereka dapatkan sebagai bentuk dari kompetensi positif di dunia kerja memacu diri untuk mempelajari perkembangan IPTEKS. 
Menurut Emmitt and Pollock (1998), solusi yang dapat dilakukan dalam pembelajaran di kelas adalah dengan menggunakan media yang sesuai dan menarik bagi pesrta didik; jika diberikan sesuatu yang sesuai peserta didik akan dapat mencapai output yang diinginkan. Untuk mengembangkan kemampuan dalam proses pembelajaran, pendidik dituntut untuk senantiasa kreatif dan mengembangkan idenya. dalam hal pengembangan strategi mengajar, penggunaan media dalam mengajar, dan juga pemilihan sumber bahan ajar. Ide dan kreatifitas dalam mengajar tersebut bisa diasah dengan banyak menimba ilmu dari membaca, media yang saat ini tersedia dengan sangat beragam, dan juga didapat pada saat calon pendidik menempuh perkuliahan, khususnya mereka yang menempuh pendidikan di program studi pendidikan. Program studi Pendidikan Bahasa Inggris memiliki beberapa mata kuliah yang bisa me-nunjang proses pembentukan kreatifitas seorang guru. Dalam setiap mata kuliah tersebut, dosen merupakan seseorang dituntut untuk menempa para calon pendidik untuk menjadi guru yang kreatif dan mempunyai ide yang inovatif.

Program Studi Pendidikan Bahasa Inggris memiliki mata kuliah yang berperan penting dalam mengembangkan ide dan kreatifitas para calon pendidik dalam pengajaran di kelas yakni mata kuliah "Instructional Media".

Menurut Burhanuddin (2005), media adalah alat yang digunakan untuk mengubah pesan atau informasi dari 'sumber' kepada 'penerima'. Dalam hal Instructional Media atau media pem-belajaran, media berfungsi sebagai alat yang digunakan oleh guru untuk membantu menyampaikan materi pelajaran kepada murid atau peserta didik secara efektif dan efisien dan sesuai dengan tujuan pembelajaran. Gerlach dan Ely (1980) menyatakan bahwa instructional media memainkan peranan utama dalam desain 23 dan penerapan instruksi pembelajaran yang sistematik. Pelajaran Bahasa Inggris yang nantinya akan disampaikan oleh calon pendidik kepada siswa mereka pada saat mereka sudah menjadi guru akan terasa membosankan apabila diajarkan dengan media, metode dan strategi yang monoton. Nowrozy dalam Cahyono dan Megawati (2013) mengemukakan bahwa penggunaan media dalam metode pengajaran tatap muka langsung berguna untuk meningkatkan interaksi dalam kelas-kelas pengajaran bahasa Inggris sebagai bahasa asing (EFL) tradisional.

Karenanya, supaya nanti mereka bisa menyajikan pembelajaran Bahasa Inggris dengan baik serta mencapai target yang ditetapkan, diperlukan suatu hal yang menarik sekaligus menantang sehingga para siswa nantinya juga bisa mempunyai kebebasan dalam mengem-bangkan ide mereka secara aktif dan kreatif. Salah satunya adalah dengan menggunakan Creative Writing Handbook. Creative Writing Handbook menggabungkan ide menulis sesuai dengan tema yang disampaikan oleh dosen dan kreativitas calon pendidik dalam menuangkan ide dan seni dalam menulis. dalam penerapan proses Creative Writing, penulis akan menghasilkan sebuah buku yang disebut sebagai Creative Writing Workbook atau Creative Writing Handbook. Untuk menghasilkan Creative Writing Handbook, beberapa langkah berikut ini dapat dilakukan sebagai permulaan (Mills, 2006, 30):

1. Mulai dengan menyiapkan sebuah Writer's workbook. Mulailah mencari dan mendengarkan apa yang ada disekitar. Tuliskan apa yang disaksikan, misalnya di jalan, di antara orang-orang, atau di acara publik. Temukan kata-kata terbaik untuk menangkap hal-hal yang terjadi tersebut.

2. Menulislah secara teratur setiap hari. Jika tidak ada yang ingin ditulis, cobalah untuk menulis bebas. Jangan menghawatirkan 
koheren atau topik tertentu ynag harus ditulis. Just write.

\section{METODE PENELITIAN}

Penelitian ini menggunakan desain Penelitian Tindakan Kelas (PTK) dengan tujuan untuk memeriksa atau menemukan bagaimana Creative Writing Handbook bisa meningkatkan kemampuan mahasiswa semester empat jurusan Bahasa Inggris Universitas Kanjuruhan Malang. Penelitian tindakan dilakukan di dalam kelas untuk memperbaiki kualitas proses pengajaran supaya proses pengajaran menjadi lebih efektif.

Penelitian ini menerapkan beberapa tahapan yakni perencanaan, penerapan perencanaan, pengamatan, serta evaluasi proses penerapan metode. Hasil dari evaluasi ini menentukan apakah penelitian perlu dilanjutkan untuk mengadakan siklus berikutnya atau tidak. Jika hasil yang diterapkan tidak sesuai dengan kriteria keberhasilan maka peneliti akan melanjutkan ke siklus ke dua.

Penelitian ini dilakukan terhadap para mahasiswa semester empat Universitas Kanjuruhan Malang. Semua siswa di kelas ini merupakan subyek penelitian. Kelas ini dipilih sebagai subyek penelitian karena beberapa alasan. Alasan yang pertama karena banyak mahasiswa di kelas ini kurang berperan aktif dalam pembelajaran. Yang ke dua, Creative Writing Handbook belum pernah diterapkan dalam pembelajaran di kelas ini. Yang ke tiga, sebagai seorang pengajar, peneliti berusaha untuk melakukan inovasi untuk membantu para mahasiswa meningkatkan kemampuan berbahasa Inggris, khususnya dalam Mata Kuliah Instructional Media.

\section{Prosedur Penelitian}

Model penelitian tindakan kelas yang digunakan dalam penelitian ini mengikuti model milik Kemmis \& Taggart (1988) yang memiliki empat langkah yakni (1) perencanaan tindakan, (2) pelaksanaan tindakan, (3) pengamatan, dan (4) refleksi. Seandainya siklus pertama gagal atau tidak sesuai dengan kriteria yang ditetapkan maka perencanaan akan diperbaiki dan melakukan siklus ke dua.

\section{Perencanaan}

Pada tahap ini, yang harus diselesaikan adalah (1) mempersiapkan strategi pengajaran, (2) mempersiapkan materi, dan (3) menyusun kriteria keberhasilan.

a. Mempersiapkan Strategi Pembelajaran

Dalam penelitian ini, Creative Writing Handbook diterapkan sebagai strategi pembelajaran karena Creative Writing Handbook dianggap bisa mefasilitasi para mahasiswa dalam mengenbangkan ide-ide dan kreatifitas mereka dalam pembelajaran media.

\section{b. Persiapan Media dan Materi}

Setelah strategi pembelajaran siap, maka peneliti juga akan mempersiapkan materi yang akan digunakan untuk diterapkan kepada mahasiswa dengan menggunakan strategi yang telah tersebut di atas. creative writing handbook merupakan cara baru bagi mahasiswa dalam pengajaran Instructional Media yang membuat mereka senang karena mendorong mahasiswa untuk berkreatifitas menciptakan suatu cerita yang disertai atau digabungkan dengan seni.

c. Menyusun Kriteria Keberhasilan

Kriteria keberhasilan disusun untuk mengetahui apakah pengajaran berhasil atau tidak. Apabila hasil dari penelitian nanti sesuai dengan kriteria keberhasilan, maka penelitian tindakan kelas bisa diakhiri. Namun sebaliknya apabila hasil tidak sesuai dengan kriteria keberhasilan maka akan dilakukan penerapan siklus ke 2. Kriteria keberhasilan bagi penelitian ini adalah $80 \%$ dari total jumlah mahasiswa yang mengikuti Mata Kuliah Instructional Media mampu menentukan dan membuat 
Creative Writing Handbook berdasarkan tujuan pembelajaran yang harus dicapai dengan menggunakan.

\section{Pelaksanaan}

Pelaksanaan merupakan perwujudan dari apa yang sudah direncanakan. Dalam pelaksanaan peneliti pertama berperan sebagai pengajar sedangkan peneliti ke 2 berperan sebagai kolaborator yang bertindak sebagai pengamat. Dalam penelitian ini, peneliti dalam pengajaran mata kuliah Instructional Media memberi-kan strategi bagaimana meningkatkan ide dan kreativitas para mahasiswa melalui pembuatan creative writing handbook. Pelaksanaannya akan dilakukan selama satu semester yaitu selama semester genap. Tes diadakan pada akhir siklus.

\section{Pengamatan}

Pengamatan adalah proses pengambilan data mengenai semua aspek dan kejadian yang berlangsung selama penerapan teknik yang sudah ditentukan. Tujuan dari pengamatan adalah mengamati apakah penerapan strategi yang dilakukan di dalam kelas mengatasi permasalahan atau tidak.

Peneliti mempersiapkan lembar observasi, lembar catatan tambahan, dan kuesioner. Lembar observasi digunakan untuk mengumpulkan data mengenai kegiatan pengajar dan mahasiswa selama proses belajar mengajar. Lembar tersebut terdiri dari keterlibatan mahasiswa, kegiatan mahasiswa selama proses belajar, dan performa pengajar.

\section{Refleksi}

Aktifitas utama dalam refleksi adalah membandingkan hasil pengamatan dan kriteria keberhasilan yang ditentukan. Hasil refleksi digunakan untuk mempertimbangkan tindakan berikutnya. Apabila hasil dari refleksi dalam suatu siklus menunjukkan bahwa hasil tidak memenuhi kriteria yang telah ditentukan, maka peneliti harus menganalisa hal-hal yang harus diperbaiki, melakukan rencana kembali dan menerapkannya pada siklus selanjutnya.

\section{Analisis Data}

Untuk menganalisa data yang sudah terkumpul, dilakukan prosedur yakni mengklasifikasi data dan menyimpulkan data.

1. Klasifikasi Data

Data diambil dari sumber-sumber yang berbeda. Data yang diambil dari hasil tes yang diberikan setelah siklus berakhir dan data dari kuesioner digolongkan sebagai data kuantitatif sementara data yang diambil dari hasil pengamatan dan catatan tambahan digolongkan sebagai data kualitatif. Data diambil dari sumber-sumber yang berbeda.

\section{Penyimpulan Data}

Penyimpulan data dilakukan setelah mengevaluasi dan menginterpretasi data. Dalam hal ini ada dua kesimpulan yakni kesimpulan pada setiap siklus dan kesimpulan akhir. Kesimpulan pada setiap siklus menentukan perlu tidaknya diadakan siklus berikutnya sementara kesimpulan akhir secara eksplisit menggambarkan model pengajaran Instructional Media yang sudah diperbaiki dengan menggunakan Creative Writing Handbook.

Data yang diambil dari hasil tes ditayangkan di tabel dan kuesioner dikalkulasi dalam presentase dengan menggunakan penghitungan frekuensi seperti berikut:

- Rumus untuk mengidentifikasi pencapaian mahasiswa dalam tes:

Nilai $=\underline{\text { Nilai yang didapat }} \times 100 \%$

Nilai maksimum

- Rumus untuk mengetahui nilai rata-rata

$$
\begin{aligned}
& M=\underset{N}{N X} \\
& M=\text { Nilai rata-rata } \\
& \sum X=\text { Total nilai yang didapat } \\
& \mathrm{N}=\text { Jumlah mahasiswa }
\end{aligned}
$$


- Rumus untuk menghitung persentase tanggapan mahasiswa dalam kuesioner ........\% $=\underline{\text { Jumlah mahasiswa yang memilih }}$ jawaban tertentu X 100\%

Jumlah mahasiswa

\section{Instrumen atau Alat Penelitian}

Ada tiga instrumen yang dipakai dalam penelitian ini yakni kuesioner, tes, dan lembar pengamatan. Kuesioner dibagikan ke mahasiswa untuk mengetahui tanggapan mereka. Sedangkan tes diberikan untuk mengetahui pencapaian mahasiswa. Tes diberikan pada saat siklus berakhir.

\section{Lembar pengamatan}

Lembar observasi digunakan untuk mendapatkan data mengenai kegiatan mahasiswa dan pengajar selama proses belajar mengajar. Aspek-aspek pengajar yang diamati adalah cara menangani kelas, menjawab pertanyaan mahasiswa, dan sebagainya. Bagi mahasiswa, meliputi kegiatan dalam melakukan tugas, menjawab pertanyaan, dan sebagainya.

2. Kuesioner

Kuesioner ini diberikan kepada para mahasiswa setelah proses pengajaran dengan menggunakan Creating Writing Handbook dilakukan. Pemberian kuesioner kepada mahasiswa ini dilakukan untuk mengetahui pendapat mahasiswa mengenai efektifitas penerapan pembelajaran Instructional Media dengan menggunakan Creative Writing Handbook.

3. Tes

Tes digunakan untuk mengidentifikasi apakah mahasiswa sudah membuat kemajuan dalam pembelajaran. Tes dibuat oleh pengajar dan tes yang diberikan sesuai dengan topik yang sudah dipelajari oleh mahasiswa. Tes pembuatan Creative Writing Handbook diberikan untuk mengukur pencapaian mahasiswa mengenai materi yang sudah dipelajari. Pemberian tes dilakukan setelah siklus berakhir.

\section{Kriteria Keberhasilan}

Kriteria keberhasilan disusun untuk mengetahui apakah pengajaran berhasil atau tidak. Apabila hasil dari penelitian nanti sesuai dengan kriteria keberhasilan, maka penelitian tindakan kelas bisa diakhiri. Namun sebaliknya apabila hasil tidak sesuai dengan kriteria keberhasilan maka akan dilakukan penerapan siklus ke 2. Kriteria keberhasilan bagi penelitian ini adalah $80 \%$ dari total jumlah mahasiswa yang mengikuti Mata Kuliah Instructional Media mampu menentukan dan membuat Creative Writing Handbook berdasarkan tujuan pembelajaran yang harus dicapai, dengan nilai minimal 75.

\section{Hasil}

Hasil dari penerapan penelitian tindakan kelas ini didasarkan pada penerapan Creative Writing Handbook serta didukung oleh respon mahasiswa dalam questionnaire. Hasil penelitian ini sekaligus juga menjawab pertanyaan yang diformulasikan dalam rumusan masalah pada bab I. Selama penerapan penelitian pada siklus 1 dan siklus 2 peneliti menggunakan topik: "describing something or someone" yang dibahas dalam penerapan Creative Writing Handbook serta diambil dari buku yang disesuaikan dengan tingkat kemampuan mahasiswa semester 4. Topik ini diambil karena menyesuaikan materi yang harus diajarkan pada mereka yakni descriptive dalam bentuk essay.

Hal ini juga didukung oleh respon mahasiswa tentang penerapan Creative Writing Handbook selama proses pembelajaran dalam Mata Kuliah Instructional Media. Selain itu hasil penelitian ini juga membahas masalah yang muncul selama penerapan Creative 
JIP, Vol.7, No. 1, Edisi Januari 2017, Hal: 22-32 Irene Trisisca Rusdiyanti, Uun Muhaji

Writing Handbook pada mata kuliah Instructional Media.

\section{Siklus I}

Peneliti mendapatkan nilai awal kemampuan menulis mereka dari nilai harian para mahasiswa. Nilai rata-rata yang diperoleh oleh mahasiswa adalah 65.34. Memang menulis essay boleh dibilang tidaklah mudah. Atas dasar itu pulalah maka peneliti menggunakan Creative Writing Handbook sebagai metode untuk meningkatkan kemampuan mahasiswa dalam menuangkan ide.

\section{Perencanaan I}

Dari hasil analisa masalah, peneliti menemukan bahwa interaksi antara dosen dan mahasiswa, mahasiswa dan mahasiswa di dalam Mata Kuliah Instructional Media kurang begitu bagus. Beberapa mahasiswa nampak pasif, mereka asyik dengan topik pembicaraan mereka sendiri, serta tidak memperdulikan penjelasan dosen. Berdasarkan pengamatan ini, peneliti berencana menerapkan penelitian tindakan kelas untuk meningkatkan interaksi didalam kelas melalui strategi Creative Writing Handbook.

\section{Penerapan I}

Pada tahap ini diperlukan penjelasan detail tentang penerapan Creative Writing Handbook. Pada proses belajar mengajar, dosen menerapkan metode membuka dan menutup pelajaran, sebagai proses pengenalan materi, kegiatan inti, dimana pada tahap ini mahasiswa mulai membahas materi yang diberikan oleh dosen. Adapun tahap ketiga adalah tahap penutup, dimana dosen menyimpulkan hasil dari pembahasan pada kegiatan inti.

\section{Pengamatan}

Pada siklus 1 peneliti memusatkan pada pengamatan di dalam kelas secara umum.
Interaksi selama penerapan Creative Writing Handbook. tidak terekam secara detail.

Berkaitan dengan masalah yang diformulasikan pada penelitian ini, maka peneliti dapat menyimpulkan beberapa hal selama penerapan Creative Writing Handbook pada Mata Kuliah Instructional Media Pada pertemuan pertama mahasiswa antusias dengan penerapan Instructional Media, namun ada beberapa mahasiswa yang belum paham apa yang harus dilakukan maka hanya sebagian mahasiswa yang bisa mengerjakan tugas yang diberikan oleh dosen dengan baik.

Pada pertemuan yang kedua, dosen meminta mahasiswa untuk mengemukakan pendapat, kesulitan, dan kemudahan yang mereka dapat dengan menulis secara berkelompok untuk ide umumnya namun mengerjakan secara individu pada pengembangan nya. Selama penerapan Creative Writing Handbook mahasiswa dan dosen melakukan interaksi dengan bertanya, menjawab pertanyaan serta memberikan komentar. Interaksi ini terjadi ketika dosen memberikan tugas kepada mahasiswa, dan mahasiswa melakukan interaksi antar mahasiswa ketika mereka mambahas tugas yang diberikan oleh dosen di dalam group maupun pada waktu mengerjakan tugas secara individu.

Pada pertemuan yang ketiga, peneliti menemukan fenomena yang berbeda pada penerapan Creative Writing Handbook. Pada dasarnya ada banyak kesempatan bagi dosen dan mahasiswa untuk melakukan interaksi selama penerapan Creative Writing Handbook. Interaksi ini dapat dilakukan melalui tugas yang diberikan oleh dosen, memberikan informasi, serta komunikasi langsung untuk memecahkan permasalahan yang terjadi selama penerapan Creative Writing Handbook. Pada penerapan metode ini mahasiswa lebih mempunyai tanggung jawab dalam belajar serta berusaha untuk memahaminya. 
Pada pertemuan yang ketiga ini peneliti menerapkan test. Mahasiswa mengerjakan tugas yang diberikan oleh dosen. Dari sinilah dapat diketahui bahwa mahasiswa masih nampak saling memberikan bantuan kepada temannya yang nampak kebingungan dalam mengembangkan ide. Mahasiswa nampak bersemangat dan senang dalam menulis namun masih ada yang kurang lancar dan memerlukan waktu yang lama untuk mengembangkan tulisan dan kreasi.

\section{Evaluasi Penerapan Creative Writing Handbook}

Dari pengamatan yang telah dilakukan, peneliti menemukan beberapa permasalahan yang terjadi dari penerapan Creative Writing Handbook. Masalah tersebut antara lain adalah mahasiswa tidak mengikuti penerapan Creative Writing Handbook dengan baik. Mereka seharusnya meskipun secara berkelompok, namun setiap mahasiswa mengembangkan sendiri ide dan kreasinya. Dalam menuliskan kalimat, hendaknya mahasiswa bekerja sendiri. Namun ada mahasiswa yang merasa tidak nyaman bekerja dan berinteraksi di dalam kelompok, mereka cenderung tidak sabar dengan teman yang berpikir agak lama dan bertanya secara terus menerus. Dan karena merasa tidak enak kepada teman yang lain dalam kelompok, maka mahasiswa tersebut menurut dan menulis kalimat yang didiktekan teman.

Adapun kriteria keberhasilan yang ditetapkan oleh peneliti adalah $80 \%$ mahasiswa mencapai nilai akhir 75. Pada siklus pertama, mahasiswa yang mencapai nilai akhir 7.5 adalah $68.75 \%$ sedangkan $31,25 \%$ mahasiswa masih mencapai nilai akhir kurang dari 75 . Berdasarkan hasil yang diperoleh pada siklus pertama, maka peneliti memutuskan bahwa penerapan Creative Writing Handbook ini masih belum mencapai kriteria keberhasilan yang telah ditentukan, sehingga peneliti memutuskan untuk melanjutkan pada siklus yang kedua.

\section{Siklus II}

Berdasarkan hasil dari penerapan Creative Writing Handbook pada siklus 1 yang diperoleh mahasiswa yang mencapai nilai 75 masih kurang dari $80 \%$ maka penelitian ini perlu dilanjutkan pada siklus yang kedua.

Siklus kedua dilaksanakan pada 12 April 2016 - 26 April 2016. Masih sama dengan penerapan pada siklus 1 , pada siklus yang kedua ini juga menerapkan tahapan dalam penelitian tindakan kelas, yaitu: merubah perencanaan, penerapan yang terdiri dari tiga pertemuan, pengamatan, serta evaluasi hasil pengamatan. Adapun hasil dari penerapan metode tersebut dapat dijelaskan sebagai berikut.

\section{Mengubah Perencanaan}

Peneliti mencoba berkonsultasi dengan sesama dosen untuk memperbaiki penerapan Creative Writing Handbook ini, dengan memperkecil jumlah mahasiswa dalam satu group dan memperbaiki materi yang akan diberikan kepada mahasiswa.

\section{Penerapan II}

Penerapan Metode ini dilaksanakan dalam 3 pertemuan. Pada tahap ini diperlukan penjelasan detail kembali mengenai penerapan strategi Creative Writing Handbook. Pada proses belajar mengajar, dosen menerapkan metode membuka dan menutup pelajaran, sebagai proses pengenalan materi. Pada kegiatan inti, dimulai dengan memberikan kesempatan bagi mahasiswa untuk memilih group mereka masing-masing. Kemudian dosen memberikan petunjuk kepada mahasiswa untuk membuat Creative Writing Handbook. Dosen terlebih dulu mengulas teori essay. Adapun tahap ketiga 
adalah tahap penutup, dimana dosen menyimpulkan hasil dari pembahasan pada kegiatan inti.

\section{Pengamatan II}

Pada pertemuan pertama, mahasiswa diberikan kebebasan untuk memilih kelompok mereka sendiri dengan tujuan mereka bisa bekerja sama dengan lebih baik. Mahasiswa sudah lebih tahu apa yang harus dilakukan dan tidak terlalu memakan banyak waktu untuk berpikir.

Pada pertemuan yang kedua mahasiswa lebih siap dalam menulis sesuai dengan harapan peneliti. Mahasiswa nampak lebih percaya diri dalam menuangkan ide mereka dalam bentuk tulisan dan tidak perlu bertanya kepada teman yang lain.

Pada pertemuan ketiga, mahasiswa mengerjakan test yang ke dua. Mahasiswa menulis dengan antusias namun dengan hati-hati dan teliti. Dalam mengerjakan test ini mahasiswa sudah tidak memerlukan banyak bimbingan dan instruksi dari dosen. Mahasiswa dapat menulis dengan tema yang diberikan dosen dengan lancar dan tanpa ragu-ragu lagi. Mahasiswa terlihat lebih bertanggungjawab terhadap test yang deberikan oleh dosen. Hal ini menunjukkan jika mahasiswa lebih memiliki kepercayaan diri dalam mengerjakan test yang diberikan. Hasil dari test kedua ini menunjukkan adanya peningkatan kemampuan mahasiswa dalam menulis.

\section{Evaluasi Hasil Pengamatan II}

Dari hasil pengamatan didapatkan kesimpulan bahwa penerapan Creative Writing Handbook memberikan kesempatan bagi mahasiswa untuk berfikir lebih relaks, tidak terbebani. Keadaan ini sangat diperlukan untuk membuat mahasiswa lebih percaya diri dan lebih baik dalam menulis. Walaupun mereka tidak langsung lancar menulis namun sudah tampak lebih baik dalam hal menulis.

Selain itu penerapan metode ini dapat membuat mahasiswa lebih aktif dan tidak lagi pasif dalam proses belajar mengajar. Selain itu, penerapan Creative Writing Handbook dapat meningkatkan kemampuan mahasiswa dalam menulis dengan lebih lancar. Hal ini dapat dibuktikan dari hasil test mahasiswa. Pada siklus kedua ini, jumlah mahasiswa yang mencapai Kriteria Keberhasilan berjumlah 30 orang $(93,75 \%)$, berarti penelitian sudah mencapai target yang ditentukan Tim Peneliti. Maka penelitian dihentikan pada Siklus 2.

\section{HASIL DAN PEMBAHASAN Hasil Questionnaire}

Tanggapan mahasiswa dalam penelitian ini menunjukkan pendapat mereka mengenai penggunaan Creative Writing Handbook dalam pembelajaran Instructional Media. Kuesioner berisi beberapa variabel yang diukur yakni: 1) motivasi belajar, 2) hasil belajar, 3) penyelesaian tugas, and 4) hubungan sosial.

\section{(1) Motivasi belajar}

Variabel pertama ini mendapat tanggapan yang memuaskan dari mahasiswa. Ini bisa dilihat dari keempat pernyataan yang berkenaan dengan hal tersebut. Pernyataan "Saya merasa senang belajar Instructional Media dengan menggunakan Creative Writing Handbook" dan pernyataan " Dengan menggunakan Creative Writing Handbook belajar Instructional Media menjadi lebih menarik dan tidak membosankan "dipilih oleh 32 (100\%) mahasiswa.

\section{Hasil belajar}

Variabel ke dua juga mendapatkan tanggapan yang memuaskan dari mahasiswa. Seratus persen (100\%) mahasiswa mendukung 3 indikator yang ada pada variabel ini. Ketiga indikator tersebut adalah: 1) mudah 
mempelajari hal baru, 2) mengingat pelajaran dengan lebih mudah, 3) menimbulkan rasa percaya diri.

\section{(2) Penyelesaian Tugas}

Variabel penyelesaian tugas dengan indikator "dengan menggunakan Creative Writing Handbook, mahasiswa lebih bersemangat menyelesaikan tugas" mendapat tanggapan yang baik pula dari mahasiswa. 26 mahasiswa menyatakan setuju dengan pernyataan tersebut, 4 mahasiswa tidak yakin, dan 2 mahasiswa memilih tidak setuju.

\section{(3) Hubungan Sosial}

Variabel hubungan social dengan indikator "penggunaan Creative Writing Handbook bisa meningkatkan hubungan sosial" mendapat tanggapan yang baik pula dari mahasiswa. 24 mahasiswa menyatakan setuju dengan pernyataan tersebut, tidak ada mahasiswa yang memilih tidak yakin, dan 4 mahasiswa memilih tidak setuju.

\section{Masalah yang Dihadapi Mahasiswa selama Penerapan Creative Writing Handbook}

Permasalahan yang dihadapi mahasiswa, selama penerapan Creative Writing Handbook dapat dideskripsikan sebagai berikut.

\section{(1) Suasana kelas ramai}

Pada waktu penerapan Creative Writing Handbook dalam Mata Kuliah Instructional Media ini, pada pertemuan pertama pada siklus pertama, ada beberapa mahasiswa yang belum mengerti apa yang dilakukan sehingga banyak bertanya kepada temannya, sehingga suasana sedikit ramai.

\section{(2) Mengandalkan teman}

Untuk beberapa mahasiswa yang kurang baik dalam menulis, mereka berfikir terlalu lama sehingga membuat mahasiswa yang lain tidak 30 sabar dan mendikte mahasiswa tersebut sehingga tulisan yang dihasilkan bukanlah sepenuhnya hasil tulisan secara individu.

\section{(3) Kurangnya Kemampuan Berkomunikasi}

$45 \%$ dari mahasiswa tidak mampu berkomunikasi dalam diskusi kelompok secara baik. Selain itu mahasiswa juga mengalami permasalahan sebagai berikut: anggota kelompok tidak dapat bekerja sama dengan baik, mereka tidak dapat mengembangkan ide secara individu sehingga banyak bertanya kepada teman.

\section{(4) Masalah Lainnya}

Beberapa mahasiswa menyatakan bahwa mereka tidak dapat menulis dengan tata bahasa yang baik, mereka menemukan kesulitan dalam memilih kata yang tepat, sehingga mahasiswa tersebut merasa sebagai orang yang mengganggu dalam hasil kelompok.

\section{Pendapat Mahasiswa dalam Penerapan Creative Writing Handbook}

Menurut pendapat mahasiswa, penggunaan Creative Writing Handbook sangatlah bermanfaat dan menyenangkan, akan tetapi ada juga mahasiswa yang merespon negatif dari penerapan strategi ini.

\section{Respon Positif}

$36 \%$ mahasiswa menyatakan tertarik dengan adanya penerapan Creative Writing Handbook. Selain itu $70 \%$ mahasiswa menyatakan metode ini sangatlah sesuai. Selanjutnya, 33,3\% mahasiswa sepakat bahwa penerapan metode ini sangatlah menyenangkan dan sebagian besar mahasiswa $(83,3 \%)$ mahasiswa menyatakan setuju jika strategi ini digunakan lagi pada masa yang akan datang.

Mahasiswa menemukan beberapa keuntungan selama penerapan Creative Writing Handbook antara lain: (1) mahasiswa dapat 
JIP, Vol.7, No. 1, Edisi Januari 2017, Hal: 22-32 Irene Trisisca Rusdiyanti, Uun Muhaji

mengekspresikan idenya tanpa merasa tertekan; (2) mahasiswa dapat memahami tulisan sesama teman tanpa merasa tertekan; (3) mahasiswa menemukan pengalaman baru; (4) mahasiswa lebih aktif dalam proses belajar mengajar

\section{.Respon Negatif}

20\% mahasiswa memberikan tanggapan negative terhadap penerapan metode ini. Mereka berpendapat bahwa penerapan metode ini kurang menarik karena mahasiswa harus sungguh kreatif dalam mencari ide, baik berupa tulisan ataupun dekorasi buku. Beberapa mahasis-wa berpendapat bahwa penerapan metode ini memiliki beberapa kelemahan, yakni: (1) kurang efektif; (2) mahasiswa yang rajin dan pandai menjadi sedikit dominan dalam suatu kelompok; (3) mahasiswa yang pasif lebih banyak bergantung pada mahasiswa yang aktif.

Berkaitan dengan respon negatif dan positif yang diberikan oleh mahasiswa, diharapkan dosen dapat lebih meng-improvisasi penerapan Creative Writing Handbook pada materi perkuliahan. Serta diharapkan dosen lebih mampu memilih materi yang sesuai dengan tingkat kemampuan mahasiswa, serta mampu mengontrol dan memperhatikan penerapan Creative Writing Handbook sebagai strategi pengajaran di dalam kelas. Hal ini bertujuan untuk meningkatkan efektivitas dan effisiensi penerapan metode Creative Writing Handbook.

\section{PENUTUP}

\section{Kesimpulan}

Secara umum dapat ditarik kesimpulan bahwa penerapan Creative Writing Handbook dapat memecahkan permasalahan yang terjadi. Lebih khusus dapat pula ditarik kesimpulan bahwa dengan penerapan metode ini dapat meningkatkan interaksi antar mahasiswa, interaksi dosen dan mahasiswa, serta dapat pula memecahkan permasalahan yang terjadi di 31 kelas, khususnya untuk Mata Kuliah Instructional Media dengan menggunakan Creative Writing Hand-book.

Berkaitan dengan interaksi antar mahasiswa, peneliti dapat menyimpulkan adanya peningkatan interaksi positif antar mahasiswa. Hal ini juga meningkatkan partisipasi aktif mahasiswa dalam Mata Kuliah Instructional Media. Hal ini dapat ditunjukkan dengan partisipasi aktif mahasiswa dalam group dan dalam kelas. Selanjutnya, strategi ini juga memberikan kesempatan bagi mahasiswa untuk lebih berkreasi.

Berkaitan dengan interaksi antara dosen dan mahasiswa dalam Mata Kuliah Instructional Media, dapat diketahui bahwa terjadi peningkatan dalam interaksi antar dosen dan mahasiswa selama penerapan metode Creative Writing Handbook. Mahasiswa lebih merasa bebas untuk mengungkapkan kesulitan yang mereka hadapi selama mengikuti Mata Kuliah Instructional Media. Selain itu mahasiswa juga dapat mengungkapkan ide secara tertulis tanpa merasa tertekan.

Ada beberapa masalah yang muncul selama penerapan strategy ini yakni situasi kelas sedikit ramai, kurangnya waktu, dan beberapa mahasiswa belum bisa mandiri dalam menulis. Akan tetapi masalah ini tidak nampak lagi ketika mahasiswa mulai menyadari bahwa mereka memiliki tanggungjawab untuk selalu aktif dalam diskusi kelas. Mahasiswa banyak yang kurang tepat dalam pemilihan kata, dan hal ini dapat dipecahkan oleh sesama mahasiswa selama proses pembelajaran. Setelah menulis, mereka mendiskusikan permasalahan yang dihadapi dan saling memberi masukan.

Adapun kesimpulan yang dapat ditarik adalah penerapan Creative Writing Handbook dalam Mata Kuliah Instruc-tional Media dapat meningkatkan kemam-puan mahasiswa dengan mengurangi rasa tertekan mereka. Hal ini dapat dibuktikan dari hasil test pada cycle 2, dimana 
lebih dari $80 \%$ mahasiswa memperoleh nilai rata-rata 7.5. Mahasiswa juga memberi-kan komentar bahwa metode ini banyak memberikan kemudahan kepada mahasis-wa, dan dosen juga dapat menerapkan strategy ini di masa yang akan datang.

\section{Saran}

Berdasarkan hasil temuan penelitian, peneliti memberikan beberapa saran dengan tujuan untuk meningkatkan kualitas proses belajar mengajar.

Peneliti menyarankan agar dosen-dosen pengampu Mata Kuliah Instructional Media dapat memperbaiki strategi ini karena strategi pembelajaran dengan menggunakan Creative Writing Handbook sangatlah menyenangkan dan mudah untuk dilaksanakan di dalam kelas.

Bagi peneliti yang lain, metode ini dapat diterapkan untuk pengajaran matakuliah keahlian yang lain, misalkan writing.

\section{DAFTAR PUSTAKA}

Burhanuddin,Yusak. (2005). Administrasi Pendidikan. Bandung: Pustaka Setia.

Cahyono,B.Y.,\& Megawati, Fika (Ed.) (2013).

Materials and Media in English Language

Teaching Malang: State University of Malang Press

Emmitt, Marie, \& Pollock, John (1998). Language and Learning: An Introduction for Teaching. Second Edition. Australia: Oxford University Press.

Gerlach, Vemon S. \& Donald P. Ely. (1980). Teaching and Media; a Systematic Approach, Second Edition. New Jersey: Prentice Hall.

Kemmis, S.,\& Mc Taggart, R. (1988). The Action Research Planner.Victoria: Deakin University Press.

Mills, P. (2006). The Routledge Creative Writing Coursebook. New York: Routledge. 